\title{
Critical Mind and Labouring Body: Caste and Education Reforms in Kerala ${ }^{1}$
}

\author{
Sunandan $\mathrm{K} \mathrm{N}^{*}$
}

\begin{abstract}
Exploring the various educational reform programs implemented in primary schools and high schools in Keralam in India in the last two decades, this paper seeks to analyze the dichotomous concepts of mental and manual labour, theoretical and practical knowledge, and general and technical education which constituted the premise of these reform interventions. The paper attempts to understand the role of different conceptualizations of language and experience in reproducing the above dichotomies. Tracing the genealogy of the dichotomies in the colonial period, the paper argues that even in the educational reform programs which consciously challenge the colonial models, one can find the continuing separation of mental and manual labour in variety of forms and modes. This leads to the question (though not answered in this paper) whether the very concept of knowledge itself, deployed in the educational practice in India, is ordered through the prism of hierarchical practices of caste.
\end{abstract}

*Assistant Professor at Azim Premji University, Bengaluru, India; knsunandan@gmail.com

1This paper is result of my postdoctoral research in Trans national Research Group funded by Maxweber Stiftung. 


\section{Introduction}

Analyzing the debate on educational reform processes in Keralam in the 1990s and 2000s, this paper attempts to understand the role of the dichotomous conceptualizations of mind and body and mental and manual labour in reproducing the colonial Brahmanical notions of knowledge. This unsettled debate regarding the educational practices in Keralam brings out the various aspects of the contemporary crisis of the colonialBrahmanical model of knowledge production. I argue that though the problem of this model is recognized at various points of the debate, the fundamental of this model is kept intact or even reinforced by various stakeholders of the educational reform processes.

The 1990s witnessed large scale structural reform programs in primary education initiated by global funding agencies and national governments in Africa, Latin America and south Asia. This was part of what is generally termed as 'new economic policies.' Scholars have studied the various historical reasons that created new initiatives for universal education. The major reason pointed out was the political agenda of globalization in which education became the new domain of economical and political domination. The critics of this new agenda have pointed out that reform programs in primary education such as the District Primary Education Programme (DPEP) and Sarva Siksha Abhiyan (SSA) initiated by the World Bank and / or national governments were aimed at the gradual withdrawal of the state from its responsibilities of primary education and the reduction of investment in formal educational institutions ${ }^{1}$. These programs while projecting social equality as their main objective, refused to address the basic factors behind the production of inequalities.

Critical scholarship has already mapped the failure of reform initiatives in challenging the continuing domination of patriarchal and casteist forces that operate in the domain of education. Most of these studies conceptualize the question of domination as problem of exclusion of the marginalized groups. This is expressed as the lack of representation of women and Dalits in the decision making bodies, lack of resources for these groups, their low enrolment and 
high drop-out rate in schools and in general as a problem of socioeconomic exclusion ${ }^{2}$. Naturally the suggestions were focused on educational programs which can become more inclusive and incorporative of marginal groups. While these explanations are valid and important, I argue that this criticism should be extended to basic concept of "school" itself, and as an extension, to the basic assumptions behind the present educational methodologies. My attempt in this paper is to shift the debate on exclusions and dominations in education from the domain of institutional to the epistemological. I attempt to locate the Brahmanical and patriarchal domination not just in the institutional structures but in the very conception of education based on the division between mental and physical labour. The major objective of this paper is to develop preliminary concepts that will help us understand education not only as a project of developing 'critical thinking but also as a project of creating 'critical action.'

The concept of "School" as the place of learning is normalized based on a fundamental binary between mental and physical labour. Since the modern education is widely accepted as a process of developing intellectual capacity, the primary target of education processes is mind and mental labour. Sarada Balagopal has argued that the discourse of child labor, based on the Western notion of bourgeois childhood as the norm, was critical in the universal child education programs. She notes that "the child is viewed as the object of nurture and care, as innocent to the world and therefore as possibly working in order to learn, but not as someone who can be made to earn and contribute to the family in a substantial manner ${ }^{3}$. Balagopal's criticism of the universal notion of childhood reminds us the importance of historicizing the very categories we use in our analysis of education and schooling. In Indian context, the superiority of "thought" over "practical work" in the colonial model is mapped into the hierarchy of castes and is institutionalized through the various dichotomous practices of schooling like formal education and vocational training, institutions of "technology" (IITs) and "technical" institutions (ITIs), centers of excellence and project for skill enhancement and so on. 
In this paper I attempt to understand how the binary of mental and manual labor was deployed, appropriated and challenged in the education reform process started from the 1990s, in relation to the contemporary caste practices in Keralam. This paper analyses the documents produced by State Council for Education and Training (SCERT) Kerala and Kerala Sastra Sahithya Parishad (KSSP) a nongovernmental organization which played a crucial role in the reform processes. In the remaining part of this paper I will first trace the genealogy of the concept of knowledge and then will explore the reform processes in the 1990s and the first decade of the twenty-first century.

\section{Genealogy of the Colonial Brahmanical Model}

The colonial educational practice in India from the beginning was part of the colonial governance. The project of governing the population in colonies was not possible by a clear demarcation between "us" and "them." While this difference was still important, for all practical purposes of governing it was necessary to create a series of objects that would connect the colonizer to the colonized. The colonial investigators defined, described and ordered objects in different hierarchical series, the two endpoints of which were the earlier binaries or dichotomies. For example, the human became a hierarchical series with European white man on the top and the aboriginal tribal man at the bottom ${ }^{4}$. Knowledge itself became a series with Knowledge and Ignorance serving at the top and bottom levels and different kinds of knowledges were arranged in between according to their supposed universality and objectivity. The construction of series as part of creating an order of knowledge was not just a discursive activity. The material practices of governing followed the same process of creating hierarchical series. A new order of institutions, actions and people was formed by creating a time - space between the 'government' and 'people' and simultaneously connecting them through middle objects. Educational institutions, Public Exhibitions, and Museums were some of the important sites which were part of this process.

The British Orientalist scholarship, which was an integral part of colonial governing practices, incorporated the existing caste hierarchy in India into series of knowledge. On the one hand, 
colonial scholars launched strong criticisms of caste practices, describing it as the tyranny of Brahmins, Eastern despotism and an archaic uncivilized tradition. On the other hand, as more and more European scholars started studying the so called "Hindu texts," they found a new ally in their project of producing knowledge about the colony ${ }^{5}$. This partnership - though it was never an equal partnership - constructed a relation between traditional knowledge and the Brahmin caste. The colonial concept of knowledge as text was crucial in inventing the traditional wisdom of the East. The colonizers considered writing as one of the most important measures of knowledge, and they arranged oral and other bodily practices of knowing at the lower level of the knowledge series. In India, in the process of creating the middle objects of the series, colonialists regarded Brahmins as the authority on traditional knowledge as they were considered the authors of written Sanskrit texts.

Within the colonialist imagination, caste was the essential stratification criteria of Indian society, and hence colonial activities in the domain of knowledge were reflected through the prism of caste. There was not much confusion regarding the nature of institution that would be appropriate for the upper caste elites among the natives. According to the colonialists, the upper castes, especially the Brahmins, were the group who were capable of attaining higher learning in literature, natural philosophy and mathematics ${ }^{6}$. In all the three universities that were established in India in the middle of the century, there was no restriction, technically, for individuals from any caste group joining the institution. But the upper caste dominated these institutions and continues to do so even in the twenty-first century ${ }^{7}$.

Colonial education policy, especially in the late nineteenth and early twentieth century, mapped the hierarchical caste system into a series of hierarchical educational institutions. The new universities were the place of upper caste, whereas the industrial training centers were the proper place of artisanal castes ${ }^{8}$. In short, what we see as colonial knowledge by the end of the nineteenth century was already a colonial - Brahmanical knowledge in content and in its form. 
Although in this period the upper castes in general dominated among the natives in the field of colonial knowledge practice, the majority of the community did not engage either in traditional or modern forms of production of knowledge. Different lower caste groups engaged in knowing practices in the field of agriculture, architecture and handicrafts, as a community. Historically, Brahmins as a community were never part of any field of knowledge, but individuals from their caste have been engaging in fields like medicine, astrology and literature. It was the colonial Brahmanical discourse on traditional knowledge that authorized the community as the sole carriers of traditional knowledge.

Even the recent scholarship, inspired by the Dalit criticism of Brahmanism, incorporated the above notion of traditional knowledge, of course in this case as an example of caste discrimination and oppression. In this narration, Brahmins using their political and social power, deliberately excluded lower castes from attaining textual knowledge ${ }^{9}$. But as we see above, it was only in the context of colonial construction of traditional knowledge in India as the Sanskrit tradition in the form of written knowledge that the Brahmins started justifying their dominance based on possession of knowledge. In the pre-colonial period this Brahmanical texts were more part of upper-caste ritual practices over which Brahmins had the monopoly and in which they prevented entry of any other castes.

From this genealogy we can map some of the general principles of the colonial-Brahmanical model of knowledge production. In this conceptualization, knowledge is a disembodied object which could exist without human presence and which could be exchanged like any other object. Written form is the most appropriate form of knowledge though other forms like spoken word can carry knowledge but less accurately. Knowledge is representation of outside reality but in practical purpose it can even substitute this reality. Since knowledge is an object that has to be produced knowledge production and knowledge transfer became two separate activities. The objective of teaching or education in general is to transfer of already produced knowledge and the production of knowledge is generally marked under the category of research ${ }^{10}$. 
The educational institutions and practices in postcolonial India were more or less a continuation of the colonial practices especially in their concept o knowledge production and knowledge transfer. The plans and priorities in institution building in the education sector reflected the hierarchical series of knowledge constructed in the colonial period: a series with knowledge at top and ignorance at the bottom. Paralleling to this notion the government established research institutions and universities as the highest level of knowledge and at the bottom adult education programs to open schools for the illiterate and uncivilized majority who were not yet qualified to be the full-citizens of the new nation.

\section{The Education Reform programs in Keralam in 1990s}

It is in the context of implementation of District Primary Education Program (D.P.E.P) in 1996 that the content, method and purpose of education became a subject of contestation in Keralam for the first time after the state formation. The earlier concerns were mainly focused on the question of administration and management of educational institutions and in establishing schools in every village in the state ${ }^{11}$. By the 1970s itself the latter goal was already achieved at least in the lower and upper primary level. Between 1971 and 1991 only four new lower primary schools were started, which shows that the question of availability of educational facility was no more a major concern. The major concern in the 1970s was the increasing drop out rate parallel to the increase in enrolment rate. It was the children from same section of population, that is, the children from lower caste communities that 'caused' the increase in both enrolment and dropout rates.

The first attempt to address the issue of increasing dropout rate by the state government in 1980 was known as 'whole promotion scheme.' According to this measure all the students were promoted from the first standard to second standard without considering the evaluation results. This was extended up to the tenth standard where $90 \%$ of the students, irrespective of their academic abilities, got automatic promotion. This was actually an administrative solution for an academic problem. At this period, the policy makers did not consider that the problem of drop out might be related to issue of curriculum or pedagogy. It was during 
the revision of curriculum in 1997 that academic questions were brought into the table as part of the implementation of the DPEP project.

The objectives of the District Primary Education program, a World Bank funded central government project, did not directly include reforms in curriculum or pedagogy. The program's main objective were to enroll and retain all the children in the aged group of 6 to 11 in primary schools, promotion of girls' education, and reduction of disparities of all types in the primary education sector. The first phase of the project, which began in 1994, included three supposed to be backward districts from Kerala. In the second phase which began in 1996 three more districts were added to the program.

In 1997, the state government decided to develop a new curriculum for the primary classes as part of the DPEP with the view that the objective of the program cannot be achieved merely by improving the infrastructure facilities and administrative reforms. The input from the left oriented non-governmental organization the Kerala Sasthra Sahithya Parishath was crucial in this decision. The State Council for Education Research and Training took initiative of conducting workshops and training programs for the development and implementation of a new curriculum. New text books for class I to class IV were introduced in all the six DPEP districts in 1998 and the government decided to expand this reform to all schools under the state board in Kerala.

The SCERT report on the workshop for curriculum development which was held in 1999 reflects the major concerns regarding the existing curriculum and the need for a new curriculum with new objectives and programs in the education sector ${ }^{12}$. The approach paper for this workshop criticizes then existed curriculum for its content, methods and objectives. The document notes that teaching and pedagogic approaches still continues as it was in the time when only a few upper caste children were part of the education system. The year old curriculum does not consider the social and cultural context of the children from other sections of the community who are now enrolled in schools. It does not develop democratic consciousness or social awareness among children Neither it is useful for satisfying the productive needs of the society 
nor is it useful in developing skills for jobs in the primary sector like agriculture or industry ${ }^{13}$.

The approach paper someway traces the genealogy of current education system to the colonial period. The paper explains:

The education program in the colonial period was a tool in reinforcing the colonial domination. The education report in 196466 had noted the importance of restructuring this system. Even though various governments and expert committees have taken some initiatives in this direction, many elements of colonial system still remain in the educational practices in Keralam. These elements help a minority to sustain their domination using the power of knowledge ${ }^{14}$.

This description or the following criticism of the existing system does not clearly explain the nature of the elements of the colonial system which is stated as remaining in the current system. In other words it does not answer to the question 'what is colonial in the present educational system.' Even then we could see some indirect reflection on this question when the paper analyses the relation between education and material production processes. The report states:

The current education is an intellectual practice which does not have any relation to the social life or the world of labour. The integration of physical and mental labour will help increasing the quality of the both. Learning can be rejuvenated through experiences from productive labour. Similarly learning will help increasing the productivity of laborers. This relation (between mental and manual labour) is an organic relation. Hence, the various parts of knowledge (that is physical and mental) are branches of the same tree ${ }^{15}$.

The approach paper criticizes the current system for its focus on the development of one form knowledge which is part of the mental labour and recognizes manual labour also as part of the educational practice. The report mentions that "the emphasis should be on learning the dignity of labor and developing capabilities to do mental and manual labour"16. Under the title 'Learning Objective' the paper explains the proposed content for a new curriculum. According to this proposal students should learn language, 
mathematics, environmental studies, physical work, health and hygienic life practices, various art forms and moral values. The idea is to develop capabilities of mind and body ${ }^{17}$. In the proposed curriculum, training in physical labour is a part of curriculum from the primary stage to the higher secondary stage. For the secondary stage, for example, it mentions that "the student learns a particular vocation / physical labour, which will be useful for social life. This would either help the student to get a job in that trade or to develop further skill and knowledge about that trade"18.

According to the proposed plan in the approach paper, from the secondary stage onwards students will slowly decide whether to move into a career that will require physical labour or to a vocation which mainly involve mental labour. In the secondary stage they will undergo basic training in both the above and in the higher secondary stage students will select one of the three streams: academic, academic/vocational, or vocational. The paper explains these three streams as follows:

Academic courses will be in environmental sciences, social sciences and in language studies. The knowledge the student will learn through these courses will be useful either for admission in professional courses or for higher studies in the subject. The second stream, the academic/ vocational courses, will be useful to find self-employment or jobs in various trades and also to develop knowledge for further improving the chances in one's own trade. The main subjects in this stream will include commerce, masscommunication, printing and computer software. The last stream will be fully vocational training which will be useful in industrial or agricultural trades ${ }^{19}$.

The draft approach paper is not the only document that emphasized the equal importance of the development of manual and mental labour in the educational practice. The draft curriculum for the secondary schools formulated by SCERT in 2002 focuses on 'activity- oriented' learning where physical work is part of the curriculum ${ }^{20}$. The draft suggests that workshops, agricultural field and technical institution around the school should be part of the school and students should work in these places. Even the language study should be based on physical activities ${ }^{21}$. The Education commission report submitted to the government in 2004, 
also gives impetus to activity oriented learning. The report suggests that "the student centered activities would be more physical and involve concrete "materials'"22. The report is in the view that the current system of education is reason for the increasing disrespect to manual labour in Keralam.

What is important here for our purpose is the invisibility of caste as an analytical category in this analysis. The approach paper discussed earlier points towards the need for questioning the discrimination based on class, caste, gender and religion, and further the history of these discriminations is traced to the colonial period $^{23}$. But the critique fails, or refuses, to identify the colonial model as colonial-Brahmanical model. It underscores the problem of the hierarchy of the mental and physical labors but does not trace its genealogy into the caste hierarchy and caste practices.

In a close examination we could see that the reform discourse still retains a concept of separate existence of manual and mental labour even while they are both part of education system. The reformers want to create 'awareness' among the students about the dignity of manual labour. But it does not mark this as a Brahmanical idea or a form of present day casteism. For all practical purposes, the new curriculum retains the hierarchical series of knowledge where the most intelligent student seek mental labour, the average student becoming part of supervising job and the below average student becomes a worker. And in practice this clearly paralleled the hierarchical series of caste in the order of upper castes - middle castes - lower castes from top to bottom. The report on vocational schools in Keralam has pointed towards this caste hierarchy in indirect terms. The report states:

Only $5.47 \%$ of the parents of Vocational Higher Secondary School (VHSC) students have an income of Rs. 8000/- and above per month. Only very low percentage (8.85) of parents with high educational qualification prefer to send their children to VSHC. Further only a small percentage of parents with technical education send their children to VHSC. Most of the parents belong to the low income group and come from the lower strata of the society ${ }^{24}$.

The report does not take caste as a category in its statistical analysis. But from other government reports and studies, it could 
be extrapolated that the majority of the lower strata of the society, mentioned in the above report, is constituted by the lower caste groups in Keralam ${ }^{25}$. This shows that creating awareness among students itself will not challenge the hierarchical practices in the field of education. It is not easy to challenge the preference of parents without challenging the hierarchy in which 'jobs of mental labour' are positioned superior in status to the 'vocations of physical labour.'

It is also interesting to note that the reformers claim the authenticity of their arguments regarding activity oriented education program and the importance of manual labour based on theories of child psychology. This is because education is still conceptualized as a process for constructing a critical mind and in this sense it is important to understand how mind works. A number of books were published by Kedrala Shasthra Sahithy Parishath explaining the theories behind the reform ideas. The book Vidyabhyasa parivarthanathinu Oraamukham (An Introduction to the Educational Reforms), maps each stages of educational practices to a particular school of psychological theory ${ }^{26}$. According to this work, the education policies in Keralam until 1980s is based behavioral theories of mind, the reforms in 1980s reflects the knowledge construction theories of Jean Piaget and the reforms after 1990s suggested by the current reformers anchor its arguments in social construction theories of Lev Vygotsky, all of which are theories of mind in general sense.

\section{Language and Experience}

The second important feature of the colonial-Brahmanical model is the relation among language, experience and knowledge. Language is considered a career of knowledge which represents the thought process and hence knowledge can exist only in language. The above relation between language and knowledge emerged during the colonial period. The colonial discourse produced different kinds of hierarchical series with dichotomous categories such as science and art, theory and practice and objective and subjective etc. at the higher and lower end of the series. The position of an object in the series was determined by its relation to language or more correctly to the form of language. This series 
enabled colonialists to make the Brahmanical text as a form of traditional knowledge and the artisanal practices as mere practical bodily work. The highest form of knowledge was objective scientific theory. The entry of upper castes in the field of knowledge production did not challenge this superiority of theory but questioned the colonialist assertions that India did not have a theoretical tradition. The orientalist and nationalist discourse elevated Brahmanical texts to the status of traditional knowledge. The artisanal practices and different forms of agricultural labour became practical work which does not require much intellectual capabilities. Similar processes of invalidation and primitivization of native practices happened in other colonies in Africa and Latin America as well.

From the early twentieth century onwards anthropologists have challenged the colonial concepts of tradition from various stand points. From a structural-functional position, Malinowski attempted to rationalize primitive cultures and their practices. He observed that "tradition is a fabric in which all the strands are so clearly woven that the destruction of one unmakes the whole" 27 . In his analysis on South African native communities, Malinowski criticized the colonial attempt to modernize "the tradition of people living in the simple tribal conditions of Africa" through "schooling of unblushingly European type" 28 . While Malinowski and several other anthropologists in this period critiqued colonial claims of superiority, these criticisms still privileged the binary of modernity and tradition, but now from a cultural relativist stand point.

The 1980s and 90s witnessed a worldwide surge of new social movements which gathered protest against the alarming rate of destruction of the environment, against the destruction of the livelihoods of indigenous communities in the name of development, and against the economic exploitations through globalization. This had its own reflection in the academic scholarship on the question of knowledge and practice. Scholars began to study indigenous practices not merely as traditions but as alternative to the violent practices of modern knowledge ${ }^{29}$. This scholarship privileged and even valorized the experiential elements of indigenous practices against the objectified forms of scientific knowledge. Studies in the anthropology of the senses underscored 
the importance of taste, touch smell and aural senses in the epistemology of indigenous societies ${ }^{30}$.

Scholars who study experiential knowledge from a phenomenological perspective relocate knowledge to the realm of unconscious, impulsive and implicit thinking. For example, Peter Storkerson explains experiential knowledge as "things recalled from experiences, things tacitly or implicitly learned or acquired." According to him, "the various kind of experiential knowledge and knowing have in common the use of what is termed unconscious, non-conscious or implicit thinking, which does not involve explicit, expressible, analyzable theoretical system of knowledge" 31 .

Once the linguist turn in the academic scholarship brought forward the impossibility of experience outside language the theory of the connection between knowledge and language was reinforced ${ }^{32}$. This turn shifted the focus of debate from experience to 'texts'; texts in various sense: from its very general concept as text book and written text to the very particular sense where post-structuralist theories used the term. Even now the text book is a crucial domain in which ideological contestations and debates of educational policy are taking place.

The educational reform process in Keralam in the last two decades one way challenged the importance of text book in schools; at the same time it retained the relation between knowledge and text in another sense. The section which deals with textbooks in the Education Commission Report of 2004 is a good example for this. In the earlier part of the report the Commission has emphasized the importance of child centric and activity oriented learning practices. The conventional idea of text book as all source of knowledge is irrelevant in this new practice. The report states:

If school education is to be made 'totally student-centered', the role of the textbooks and the manner in which they are used would certainly need to undergo drastic changes. The textbook would no longer be the repository 'of all the knowledge' that the student is expected to learn. It would be just one in an infinite array of material with which the student interacts in her course of journey of discovery, as she builds knowledge ${ }^{33}$. 
The report adds that "in fact the word 'textbook' itself could be a misnomer, since the content of the books would be designed essentially as 'triggering off' points from where the actual process of self learning begins" 34 . This criticism of the role of textbooks, in one way, questions the objectified nature of knowledge which could be transferred from the teacher to the student through textbook. The mention about self learning and journey of discovery implies that knowledge is not an object that could be handed down, but it is gained as a process. Does this challenge the colonialBrahmanical idea of the relation between knowledge and text? We can answer this question by analyzing the other materials in 'the infinite array of materials with which the student interact.' The report continues:

A variety of additional reading materials supplements, newspapers, magazines and reference books would have to be made available to the learner on a regular basis. It is in this context that the school library would assume added significance ${ }^{35}$.

It is clear that most of materials in the infinite array are texts and most of the activity that are suggested in activity oriented learning are activities of reading writing and speech all of which could be termed as language activities. For example the curriculum draft prepared by SCERT for secondary school lists some activities for learning social sciences at secondary level. This includes, visiting of libraries, collecting journals and other audio-visual materials, collecting historical documents, interviews with important individuals in the neighborhood and so on ${ }^{36}$. These activities are designed in order to develop a critical mind which is the final objective of education. Thus the reform discourse keeps the divide between mental and physical labour intact.

\section{Theory and Practice}

The very process through which the curriculum was designed and implemented is another example where the theory - practice divide was kept unchallenged or even reinforced. The process began with formation of an expert committee of teachers and scholars to design the draft of the curriculum. The workshop of selected forty experts discussed and debated the theoretical issues and formed a 
curriculum and draft approach paper for a new pedagogy. How to implement this new curriculum was not decided in this workshop. To decide the actual activities in the class room, district level and block level workshops were organized including all primary school teachers. In these workshops teachers themselves had to design activities for each content prescribed in the curriculum. The very process created experts who created theories and practitioners who designed and implemented the program.

The words of the one of the experts who participated in this workshop explain the conceptualization of the reformers regarding theory and practice. In an interview he described an event in the workshop for text book creation.

"We were almost finishing the design of Malayalam text books when the Director of the program brought an outside person, who was an Adivasi and social activist. The activist evaluated the texts and thoroughly criticized it for its upper-caste Hindu language. Then we recognized that we have to start again from the beginning." This cannot be a surprise looking into the caste characteristics of the committee. Out of the forty members, 35 were from upper caste and 33 of them men. To my question whether this Adivasi activist was included in the further deliberation he said that "Oh no, but we consulted with some of the Dalit and Adivasi activist and incorporated some of their view after critical scrutiny." To another question of lack of representation of Dalit, Adivasi, and women members the expert explained that "this committee did not follow reservation norms. The members were selected purely based on their scholarship and prior experience in this field. The objective of the workshop was to discus the ideological and theoretical issues. But once the curriculum was formulated, it was discussed in public forums in a democratic manner"

The debate and criticism that came out in the public sphere after the implementation of the program also points towards the concept of superiority of theory over practice. The main criticism about the program from the public was that it has diluted the content and the students will not be able to compete with other students under the CBSE board. Since this was implemented only in Government and Aided schools this was considered as part of the World Bank agenda of destroying the opportunities of the weaker sections in 42 
the society. At this point the defenders of the program introduced more theoretical works to justify the new program. In a book Lev Vygotsky ad Education, author P.V. Purushothaman states in the introduction:

This book is important in two ways. First it introduces the contributions of one of the most important thinkers of education to the readers. Second, it helps to gain ideological clarification regarding the educational reform processes that is happening in Keralam. This book proves that the present reform of curriculum is not part of a hidden agenda of any individuals or organizations like Kerala Shasthra Sahithya Parishath, rather it is baked by the debates happening worldwide on education ${ }^{37}$.

Most of the critiques of the reform did not challenge the theoretical assumption of the current reformers or psychological theories of Piaget or Vygotsky. For example, one critique explains:

Our objection is not against the ideas behind the reform program. Everyone who are familiar with the debates in education will agree that the old child psychological theories are redundant and new theories including Lev Vygotsky are important. But the question is about the practical implementation. Are our teachers ready for this change and if not do we have designed any program to make them ready? Theories might not be wrong but they are not always useful or practical in certain situations ${ }^{38}$.

Both the critiques and the defenders of the program emphasized that the theory, which was after all tested by the experts in the West, cannot be wrong. The major question in the debate was whether the situation in Keralam was suitable for the implementation of the theory or can the situation be changed making it suitable for the program.

All the three issues discussed in this paper - the issue of mental and manual labour, the relation among language, experience and knowledge and the problem theory and practice - points towards the current forms of practices of casteism in the domain education. The reformers criticism against the colonial-Brahmanical concepts of mental and manual labour was limited so that the former did not consider the problems of the very notion knowledge in the latter. The reform discourse did question the present system of producing 
'theoretical Brahmins' and 'practical Shudras', but did not extend its criticism to the Brahmanical nature of the theory itself ${ }^{39}$. This analysis reminds us the importance of examining the caste practice not only in the sociological domain but also in the domain of epistemology.

${ }^{1}$ For a critique of the DPEP and its connection to the globalization agendas see, Krishnakumar, Manisha Priyam and Sadhna Saxena, "Looking Beyond the Smoke Screen: DPEP and Primary Education in India," Economic and Political Weekly, (February 17 - 23, 2001): 560-568.

${ }^{2}$ For a critical analysis of notions of gender and social equity that frame the implementation of DPEP see, Vimala Ramachandran and Aarti Saihjee, "The New Segregation: Reflections on Gender and Equity in Primary Education," Economic and Political Weekly, 37, 17 (April 27 May 3, 2002): 1600-1613.

3 Sarada Balagopalan, "Memories of Tomorrow: Children, Labor and Panacea of Formal Schooling," The Journal of the History of Childhood and Youth, 1, 2 (Spring, 2008): 269

${ }^{4}$ Kay Anderson has argued that humanism based on the nineteenth century scientific theories of human species did not assume homogeneity or equality among all human beings; instead these theories essentialized the racial differences based on biology and justified hierarchical stratifications based on race. "The colonial difference" practiced by the colonial governments in colonies was not an aberration, as Partha Chatterjee put it, of the universal theories practiced in Metropole. From the very beginning, universalism was a practice of the hierarchical ordering of objects and human beings. Kay Anderson, Race and the Crisis of Humanism (London: Routledge, 2007); Partha Chatterjee, The Nation and its Fragments: Colonial and Postcolonial Histories (Princeton: Princeton University Press, 1993).

${ }^{5}$ For example, James Mill, in his six volume work on British India, depicted the Brahmins as despotic and uncivilized. H.H. Wilson, on the other hand, objected to the general view among the colonial officers that Brahmins were "crafty and cunning." Wilson argued that Brahmins and their Sanskritic tradition were part of a great civilization upon which the whole history of India was built. James Mill, The History of British India (London: James Madden and Co., 1840); H.H. Wilson, Essays: Analytical, Critical and Philological on Subject Connected with Sanskrit Language (London: Trubner and Co., 1865). 
${ }^{6}$ Both the Orientalists like William Johnson, who favored the promotion of Sanskrit-based education, and the Utilitarians like John Stuart Mill, who was strong proponent of English education, considered Brahmins and other upper castes as the proper native group who could be "educated" and enlightened through the colonial educational institutions. For an analysis of the colonial education policy and the privileges and preferences of the Utilitarians and the Orientalists, see Bart Schultz and Georgios Varouxaki, eds., Utilitarianism and Empire (Oxford: Lexington Books, 2005).

7 For an analysis of the role of caste in the history of education see, Sabyasachi Bhattacharya, ed., Education and the Disprivileged: Nineteenth and Twentieth Century India (New Delhi: Orient Blackswan, 2002).

${ }^{8}$ Alfred Chatterton's study of Industrial education is an example of how the colonialists mapped the caste hierarchy onto a hierarchical system of education and training. He attempted to assign each caste group a specific form of education depending on their traditional occupation and a supposed historical relation with knowledge. Alfred Chatterton, Industrial Education (Madras: Govt. Press, 1901). See also George Birdwood, The Industrial Arts of India (London: Chapman and Hall, 1884).

${ }^{9}$ For example see, Sukhdeo Thorat, The Dalits in India: Search for a Common Destiny (New Delhi: Sage Publications, 2009); Kancha Ilayya, PostHindu India A Discourse on Dalit-Bahujan, Socio-Spiritual and Scientific Revolution (New Delhi: Sage Publications, 2009).

10 My attempt here is to argue that the present form of educational model based on the divide between mental and manual labour should be contexualized based on the alliance between colonialists and Indian elites and that there exists alternative forms such as artisanal model where both mental and manual labour are not only an integral part of knowledge system but not even separable.

11 For an analysis of the early education programs after the formation

Keralam as a state see, K. Govindan, Educational Reforms in the last Two Decades, Kerala Education Department, Thiruvananthapuram, 1973.

12 Curriculum Shilpashala Curriculum Workshop), SCERT, Thiruvananthapuram, 1999.

13 Ibid, p. 2

${ }^{14}$ Ibid., p.3

15 Ibid.

${ }^{16}$ Ibid., 8

17 Ibid., pp. 13-14

18 Ibid., p. 20 
${ }^{19}$ Ibid., p.23

20 Secondary School Patyapadhathi (Karat)(Secondary School Curriculum (Draft)), SCERT, Thiruvananthapuram, 2002.

${ }^{21}$ Ibid., p. 11

${ }^{22}$ Report of the Keral Education Commission, Kerala Education Department, Thiruvananthapuram, p. 17.

23. Curriculum Shilpashala, SCERT, p. 5

24 The Relevance, Scope and Problems of Vocational Higher Secondary Education in Kerala, 1998 - 1999, SCERT, Thiruvananthapuram, 2000.

${ }^{25}$ For example see Census Report of 2011,

26 Vidyabhyasa parivarthanathinu Oraamukham (An Introduction to the Educational Reforms), Kerala Shasthra Sahithya Parishath, Thrissur, 2002.

${ }^{27}$ Cited in George W Stocking, "Maclay, Kubary, Malinowski: Archetypes from the Dreamtime of Anthropology," in Stockings, ed., Colonial Situations Essays on the Contextualization of Ethnographic Knowledge (Madison: University of Wisconsin Press, 1993), 51.

${ }^{28}$ Ibid, 58.

${ }^{29}$ For a comparative analysis of scientific knowledge and indigenous knowledge see, Ladislaus Semali and Joe Kincheloe, eds. What is indigenous Knowledge: Voices From the Academy (Oxford: Taylor \& Francis, 1999); Suman Sahai et. al., Indigenous Knowledge: Issues for Developing Countries (Santa Barbara: University of California Press, 2005); Darrell Poesy and Kristina Plenderleith, Indigenous Knowledge and Ethics: A Darrell Poesy Reader (New York: Routledge, 2004).

${ }^{30}$ For the critique of Western understanding of senses see, Constant Classen, Worlds of Sense: Exploring the Senses in History and Across Cultures (London: Routledge, 1993); David Howes., ed., The Varieties of Sensory Experience: A Sourcebook in the Anthropology of the Senses (Toronto: University of Toronto Press, 1991); Mike Featherstone, Mike Hepworth, and Bryan S. T'irner, eds., The Body: Social Process and Cultural Theory (London: Sage Publications, 1991).

31 Peter Storkerson, "Experiential Knowledge, Knowing and Thinking," Experiential Knowledge Special Interest Group 2009, accessed February 18, 2012, http://web.me.com/niedderer/EKSIG/ proceedings _speakers_files/Storkerson.pdf. For a debate on experiential knowledge see Jerry Fodor, Modularity of Mind (Scranton: Crowell, 1983); Arthur S Reber, Implicit Learning and Tacit Knowledge (Oxford: Oxford University Press, 1993); George Lakoff and Mark Jobnson, Philosophy in the Flesh: The Embodied Mind and its Challenge to Western 
Thought (New York: Basic Books, 1999); Timothy D Wilson, Strangers to Ourselves (Massachusetts: Belknap, 2002).

${ }^{32}$ Criticizing Levi Strauss for his attempt to "safeguard the exteriority of writing to speech," Derrida asked: "Is there a knowledge, and above all, a language, scientific or not, that one can call alien at once to writing and to violence?" Derrida's attempt to question the Western metaphysical tradition of privileging speech over writing is important, but it fails to consider the specific historical situations where the colonialists privileged writing over speech, the act which had severe violent consequences in the colonial world. Levi Strauss, Tristes Tropiques, trans. John Weightman and Doreen Weightman (New York, Penguin, 1975); Jacques Derrida, Of Grammatology, trans. Gayatri Chakravorty Spivak (Maryland: The John Hopkins University Press, 1974), 127.

33 Report of the Kerala Education Commission, p. 19.

34 Ibid

$35 \mathrm{I}$ bid

36 Secondary School Curriculum Draft, p. 17

37 P.V. Purushothaman, Vigotskiyum Vidyabhyasavum (Lev Vygotsky and Education), Kerala Shasthra Sahithya Parishath, Thrissur, 2008.

38 Interview with M. Narayanan, School Teacher, Calicut, May 12, 2013

39 These terms were coined by Gopal Guru, in his criticism of the current practice of Social Sciences in India. Gopal Guru and Sundar Sarukkai, The Cracked Mirrors: An Indian Debate on Experience and Theory, Oxford University Press, New Delhi, 2012. 